\title{
Ecophysiological factors underpinning productivity of Hevea brasiliensis
}

\author{
V.H.L. Rodrigo* \\ Rubber Research Institute of Sri Lanka, Dartonfield, Agalawatta, Sri Lanka. *Corresponding author: laksh@sltnet.lk
} Received: 30 September 2007; Accepted: 17 October 2007

High land productivity is a must for any commercial cultivation including Hevea brasiliensis (rubber). Also, the high demand for natural rubber has placed great pressure on expanding rubber cultivation to new and non-traditional areas. Understanding the ecophysiological principles behind the measures of productivity improvements is vital for wide application of these measures and to assess their sustainability. This review discusses the ecophysiological principles and tools used, along with the measures taken, to address productivity needs in terms of: genotype selection, determination of optimum planting density, and establishment of intercropping systems. Breeding for high yields and selection of suitable genotypes for different growing conditions are a top priority throughout the research history of rubber, however, early selection tools are necessary to reduce the time required for this process. As for any crop, photosynthesis drives the productivity of the rubber crop and, therefore, factors that govern and/or parameters that indicate the efficiency of photosynthetic productivity under field conditions could be used as tools in the selection of Hevea genotypes. Particularly for the early selection of genotypes in breeding programmes, mature crop characteristics which determine crop photosynthesis and productivity, should be linked to juvenile plant characteristics. The spatial and temporal efficiency by which plants acquire growth resources determines the overall productivity of the rubber crop, hence the optimum planting density and suitable crop combinations in intercropping systems. Changes in crop microclimate influence the efficiency of resource capture and thereby can be important for determining planting density and intercrops. Research needs regarding all the above aspects are also discussed.

Key words: Rubber, Genotype selection, intercropping, planting density, physiology

Fatores ecofisiológicos afetando a produtividade de Hevea brasiliensis: Para qualquer cultivo comercial, incluindo Hevea brasiliensis (seringueira), alta produtividade é um mister a ser perseguido Ademais, alta demanda por borracha natural tem exercido grande pressão para a expansão do cultivo de seringa para novas áreas não-tradicionais. Nesta revisão, são discutidos os princípios ecofisiológicos e ferramentas usadas, bem como as medidas a serem tomadas, para direcionar o aumento da produtividade, em termos de seleção de genótipos, determinação da densidade ótima de plantio e estabelecimento de sistemas de consorciação. Melhoramento para altos rendimentos e seleção de genótipos adequados para diferentes condições de cultivo tem sido uma prioridade constante ao longo da historia de pesquisas sobre seringueira; todavia, ferramentas para a seleção precoce são necessárias são para reduzir-se o tempo requerido para esse processo. Como em qualquer cultura, a fotossíntese governa a produtividade da seringueira e, portanto, fatores ou parâmetros associados, ou que indicam, a eficiência da produtividade fotossintética sob condições de campo podem ser usados como ferramentas na seleção de genótipos de Hevea. Particularmente, para a seleção precoce de genótipos em programas de melhoramento, as características da planta adulta, que determinam a fotossíntese e a produtividade da cultura, devem ser associadas com as características da planta na fase juvenil. A eficiência temporal e espacial pelas quais as plantas adquirem recursos necessários ao crescimento determina a produtividade global da cultura da seringueira e, portanto, a densidade de plantio ótima e as combinações adequadas de culturas em sistemas de consorciação. Alterações no microclima da cultura influenciam a eficiência de captura de recursos e, assim, podem ser importantes para determinar a densidade de plantio e as espécies envolvidas na consorciação. Necessidades de pesquisa no que tange aos aspectos supramencionados são também discutidos.

Palavras-chave: consorciação, densidade de plantio, fisiologia, seleção genotípica, seringueira 


\section{INTRODUCTION}

Demand for land is ever increasing with the increase in population. Usage of rubber is highly associated with the lifestyle of people, particularly the quality of life. In keeping with the increase in population and quality of life, the demand for rubber has grown throughout the past. Environmental issues also generate a demand for natural rather than synthetic rubber, as well as sustainable productivity on agricultural lands. Nevertheless, management systems always drive for high productivity and low production costs. All these factors have a permanent influence on the growers of natural rubber to raise land productivity whilst protecting the environment. Also, to meet the increasing demand, rubber cultivation is being rapidly expanded to non-traditional areas.

As for any crop, the land productivity improvement of Hevea brasiliensis, the principal source of natural rubber, is basically three-dimensional. Use of high-yielding genotypes with desired characteristics developed through rigorous breeding and selection programmes has been the primary and principal way of obtaining high productivity of rubber latex. This particularly aims to increase the yield per tree, and the determination of correct or optimum planting density is the next approach towards high latex productivity per unit area. Intercropping practices targeting the overall land use efficiency is the third option. The aim of this paper is to discuss the details of the above mentioned approaches with underpinning ecophysiological principles and, thereby, to identify key factors involved and research needs in achieving the goals of the rubber industry in today's context. However, potential manipulation of latex productivity with different exploitation and stimulation systems will not be examined here.

\section{ECOPHYSIOLOGICAL TOOLS IN GENO- TYPE SELECTION}

Involvement in plant breeding: Being a perennial crop which requires over about five years to attain the latex harvestable stage and then at least additional seven years to assess the yields, breeding programmes of rubber take over 15 years to produce a suitable genotype. Therefore, the need for early selection methods is often emphasized. Based on the principle that plants produce basic compounds of growth and yield through photosynthesis, attempts were made to use photosynthetic efficiency together with associated factors such as water vapour diffusion as the early determinants of high-yielding genotypes (Nugawela and Aluthhewage, 1985; Nugawela et al., 1995a). Knowing the high variability of the instantaneous rate of photosynthesis due to its dependency on the incident radiation levels, key parameters of the light response curve (LRC) of photosynthesis, i.e. light-saturated level of photosynthesis $\left(A_{\max }\right.$-the photosynthetic rate at which the LRC tends to plateau) and apparent quantum yield ( $\Phi_{\text {app }}$-initial slope of the LRC) could be used in such studies. The rate of $A_{\max }$ denotes the maximum expected rate of photosynthesis under the ambient temperature and $\mathrm{CO}_{2}$ levels (light saturation stage) whilst $\Phi_{\text {app }}$ demonstrates the photosynthetic performance under low light levels (light limiting stage). In general, an equation of either a rectangular hyperbola or quadratic function (Hay and Walker, 1989; Thornley and Johnson, 1990) is used to construct the LRC and the latter provides a more accurate measure of $A_{\max }$ and $\Phi_{\text {app }}$ and also provides an additional parameter on the convexity $(\theta)$ of the LRC which represents the transition stage between light limitation and saturation.

Nugawela et al. (1995b) characterized the yield potential of some Hevea genotypes planted in Sri Lanka using photosynthetic parameters and thereby tried to establish a method of early screening for newly bred Hevea genotypes. In this study, the daily photosynthetic integral was estimated using the Charles-Edwards equation (Charles-Edwards, 1982) where $A_{\text {max }}$ and $\Phi_{\text {app }}$ are the key components. Also, water-use efficiency (WUE) in photosynthesis was found to be highly correlated with the latex yield potential (Nugawela et al., 1995b). Photosynthetic rates and WUE were greater in highyielding clones and vice versa for dark respiration rates (Nugawela et al., 1995b). Despite being an excellent approach, this method had a low level of accuracy permitting the genotype separation only into three broad categories of latex yield, i.e. high, medium and low yielding groups. Unlike small juvenile plants which behave as discrete units enabling most of the leaves to be exposed to incoming solar radiation, there is a high level of light attenuation within the closed canopies of mature rubber trees. Photosynthesis at the crop level, therefore, highly depends on canopy architecture which is generally represented by the light extinction coefficient $(k)$ and the leaf area index (LAI). It is extremely difficult to 
predict the values of ' $k$ ' and LAI of mature tree crops from the assessment in juvenile plants. Nugawela et al. (1995b) used a fixed value for ' $k$ ' across all genotypes and tried to estimate LAI of different genotypes with known differences in LAI and leaf area per whorl of juvenile plants of two specific genotypes. This was a too simplistic approach probably resulting in large variability in the protocol of early screening. Although a value of 0.6 was assigned to ' $k$ ' for all genotypes in this study, values reported elsewhere were 0.3 for the genotype RRIC100 and 0.58 for RRIC121 (Munasinghe, 2005). The angle of the petiole and leaflets, size and relative positioning of leaflets and any other characteristics such as early branching habit of juvenile Hevea genotypes could be used as determinants of the canopy architecture of mature trees. Therefore, anyone who intends to refine or develop this early selection method further could consider developing a simple model to predict ' $k$ ' and LAI of mature crops with the canopy characteristics of juvenile plants.

Performance under different climatic regimes: Although most rubber plantations were initially confined to wet regions, its cultivation has now been expanded to varying climatic regimes, particularly dry environments. Therefore, suitable genotypes are to be selected for those conditions. Although the performance in growth and yield was of the utmost importance in those studies, characterization of such responses on a physiological basis is essential to avoid the site-specific nature of the results. Moreover, such analyses could also be useful to identify suitable genotypes at early stages of evaluation in breeding programmes.

In dry environments, mechanisms by which plants conserve water, whilst maintaining a high level of productivity, must be understood. Plants avoid the effects of water stress by maintaining water uptake, reducing water loss or by osmotic adjustment. There are several mechanisms for reducing water loss in plants, including reduction in leaf area and stomata closure. The responsive mechanism or mechanisms used and the magnitude of the response depend on the genotype and ultimately decide the sustainability of productivity. Similar to most other crops, stomata of Hevea leaves are highly reactive to environmental changes (Rodrigo et al., 2005a). Diffusive resistance to water vapour and $\mathrm{CO}_{2}$ of stomata depends mainly on atmospheric vapour pressure deficit, irradiance and temperature. Also, it is particularly responsive to internal water status as measured by leaf water potential which is highly dependent on soil water status. Therefore, genotypic responses in dry conditions are generally assessed with measurements of stomatal conductance $\left(\mathrm{g}_{\mathrm{s}}\right)$ or resistance $\left(r_{\mathrm{s}}\right)$ (each being the reciprocal of the other), leaf water potential and relative water content. Also, the sensitivity of leaf expansion to water deficit is one of the mechanisms for reducing water loss. Rubber plants grown in wet regions of Sri Lanka (annual rainfall is $c a .5000 \mathrm{~mm}$ ) have shown a wide range of $r_{\mathrm{s}}$ varying from 1 to $8 \mathrm{~s} \mathrm{~cm}^{-1}$ (Rodrigo et al., 2005a). Stomatal resistance of rubber shows distinct diurnal variation with high values around midday, particularly after dry spells. With no major soil moisture deficits, the maximum of $r_{\mathrm{s}}$ is $c a .4 \mathrm{~s} \mathrm{~cm}^{-1}$ whereas it would increase over twofold under dry conditions. Any increase in $r_{\mathrm{s}}$ adversely affects the photosynthetic rates by limiting $\mathrm{CO}_{2}$ transfer (Rodrigo, 1997).

Obviously, most important is how efficiently water is consumed under water limited conditions. Water-use efficiency gives the measure of how much dry matter is produced per unit amount of water consumed. Growth and water use assessments of tree crops like rubber are rather tedious, hence only few studies have involved such measurements. In other studies, it has depended mainly on the instantaneous rate of $\mathrm{CO}_{2}$ assimilation and predicted transpiration rates based on stomatal conductance without properly taking into account the boundary layer conductance at different canopy levels. Values recorded for WUE of rubber with biomass and water consumption measurements were within the range of 1.5-3.5 $\mathrm{g} \mathrm{mm}^{-1} \mathrm{~m}^{-2}$ (Rodrigo et al., 2005a) whilst that calculated using $\mathrm{CO}_{2}$ assimilation and stomatal conductance was below $1 \mu \mathrm{mol} \mathrm{CO}_{2} \mathrm{mmol}^{-1} \mathrm{H}_{2} \mathrm{O}$ for water stress conditions (Dey and Vijayakumar, 2005) and ca. 3 $\mu \mathrm{mol} \mathrm{CO}{ }_{2} \mathrm{mmol}^{-1} \mathrm{H}_{2} \mathrm{O}$ without water stress (Nugawela et al., 1995b). Being a crop that originated in the wet tropics, water-stress conditions would not favour the efficiency of dry matter production, resulting in low values of WUE. Furthermore, rubber cultivation has benefited from banana intercropping in terms of dry matter produced and WUE, probably due to stress avoidance by the amelioration of the microclimate (Rodrigo et al., 2005a).

The Penman-Monteith equation (Monteith, 1965; Monteith and Unsworth, 1990) is generally used to estimate the amount of water loss through transpiration 
which is the principal pathway of water in plants. Instruments are available to measure the required parameters of this equation, however assessment of boundary layer conductance $\left(g_{\mathrm{b}}\right)$ is rather timeconsuming and requires continuous weighing of leaf samples in the crop canopy and then calculations using the equation to find the value for $g_{\mathrm{b}}$. The study of Teklehaimanot and Javis (1991) on $g_{\mathrm{b}}$ of Picea sitchensis gives a classic example to demonstrate tediousness of this type of assessment where a huge tree had to be suspended in air and provided with artificial rains. Therefore, suitable ecophysiological models are required to estimate $g_{\mathrm{b}}$. A model has been developed to estimate $g_{\mathrm{b}}$ of tree crops (Rodrigo et al., 2005a) and used for rubber $\left(g_{\mathrm{b}}=0.048 \mathrm{xUxLAI} \mathrm{I}^{0.381}\right.$ where $\mathrm{U}$ refers to wind speed at $2 \mathrm{~m}$ above the canopy, in $\mathrm{m} \mathrm{s}^{-1}$ ). Nevertheless, only the LAI represented the canopy architecture in this model (Rodrigo et al., 2005a) and therefore in future investigations attempts should be made to incorporate other parameters of canopy architecture such as leaf distribution.

The thermocouple-based Heat pulse/Sap flow system provides direct measurements of transpiration water loss with no hassle for assessing either $g_{\mathrm{b}}$ or $\mathrm{g}_{\mathrm{s}}$. However, there are no appropriate records available on the use of this system with rubber. According to the study of Rodrigo et al. (2005a) using the Penman-Monteith equation, a two-year-old rubber canopy would transpire ca. $5 \mathrm{~mm}$ per week in wet regions. Unfortunately, no such records are available for the dry regions. Also, effects of adaptive measures taken by rubber plants in dry regions to conserve water on overall canopy photosynthesis and latex productivity are as yet to be studied.

Rubber is grown in cooler climates particularly in China and at some high altitudes in India. Being a tropical crop, rubber is mostly grown above $20^{\circ} \mathrm{C}$ at altitudes below $200 \mathrm{~m}$. Whilst high temperatures result in high evapotranspiration and water stress, low temperatures lead to low growth rates and cold damage. Low temperatures would severely affect all metabolic activities and, in particular, result in permanent damage to the photosynthetic apparatus. Under such circumstances, photoinhibition is very common and would occur even under moderate light levels which are otherwise beneficial at optimum temperatures. Nevertheless, some selected genotypes have proven to be tolerant to low temperature. For instance, GT1 has performed reasonably well at $5^{\circ} \mathrm{C}$ in China whilst some specially bred clones could even tolerate $0^{\circ} \mathrm{C}$ for a short period (Webster and Baulkwill, 1989). However, overall productivity in such circumstance appears to be rather lower than the values recorded elsewhere indicating some level of impediments at low temperature levels. Onsite evaluation of growth and actual yields would be the most accurate way to assess a genotype; however photosynthetic efficiency could also be used for early selection even under low temperature conditions. Although $A_{\max }$ provides a useful measure, assessments of $\Phi_{\text {app }}$ and chlorophyll $a$ fluorescence emission in terms of the ratio of variable to maximum emission $\left(\mathrm{F}_{\mathrm{v}} / \mathrm{F}_{\mathrm{m}}\right)$ indicate the level of any damage to the photosynthetic apparatus (Ireland et al., 1989). Photoinhibition of the leaf photosynthetic apparatus (given by damage to the PSII protein complex) results in a major decease in the $\mathrm{F}_{\mathrm{v}} / \mathrm{F}_{\mathrm{m}}$ ratio and can be measured with a commonly available portable plant efficiency analyzer. Being a rapid measurement, fluorescence emission can be assessed in a large number of plants within a short period and hence it would appear to be a suitable measurement for shortlisting suitable genotypes. Thereafter, analysis of the light response of photosynthesis would be appropriate in early screening. The same procedure could be adopted in genotypic evaluation to some extent under dry conditions; however in rubber plants, no permanent damage of the photosynthetic apparatus has been recorded in such conditions. Instead, any short-term drop in $\mathrm{F}_{\mathrm{v}} / \mathrm{F}_{\mathrm{m}}$ ratio and $\Phi_{\text {app }}$ could be attributed to downregulation of photosynthesis. In both wet and dry climatic conditions in Sri Lanka, the $\mathrm{F}_{\mathrm{v}} / \mathrm{F}_{\mathrm{m}}$ ratio was in the range of 0.75-0.85 (Senevirathna et al., 2003; Iqbal and Rodrigo, 2006). Only under sunny conditions, has some level of decrease in the $\mathrm{F}_{\mathrm{v}} / \mathrm{F}_{\mathrm{m}}$ ratio been recorded around midday (Senevirathna et al., 2003). Similarly, $\Phi_{\text {app }}$ dropped by ca. 0.01-0.02 in the afternoon from the values of 0.050.06 in the morning (Iqbal and Rodrigo, 2006). Such down-regulation of photosynthesis limit the maximum capacity of photosynthesis affecting the $A_{\max }$ and, in addition, is more prominent in early stages of field establishment when rubber plants are small (Iqbal and Rodrigo, 2006). These diurnal and growth stage variations in photo-synthetic capacity are clearly illustrated in LRCs obtained for rubber plants established in the dry areas of Sri Lanka (Table 1; Iqbal and Rodrigo, 2006). 
Table 1: Parameters of the light response curve of photosynthetic $\mathrm{CO}_{2}$ assimilation in rubber plants grown in a dry area of Sri Lanka showing the down-regulation of photosynthesis, particularly in the afternoon, and increase in photosynthetic capacity with plant growth. $A_{\max }$ refers to the light-saturated rate of $\mathrm{CO}_{2}$ assimilation (after Iqbal and Rodrigo, 2006).

\begin{tabular}{lccc}
\hline $\begin{array}{l}\text { Age of rubber } \\
\text { plants }\end{array}$ & Time of day & $\begin{array}{c}\text { Mean apparent } \\
\text { quantum yield } \\
\left(\phi_{\text {app }}\right)\end{array}$ & $\begin{array}{c}\text { Mean } \\
A_{\text {max }}^{-2}-1 \\
\left(\mu \mathrm{mol} \mathrm{m}^{\mathrm{s}}\right)\end{array}$ \\
\hline One year & $0900-1000 \mathrm{~h}$ & $0.0511 \pm 0.0029$ & $13.05 \pm 0.5303$ \\
& $1500-1600 \mathrm{~h}$ & $0.0422 \pm 0.0030$ & $12.20 \pm 0.9546$ \\
Two years & $0900-1000 \mathrm{~h}$ & $0.0585 \pm 0.0068$ & $15.20 \pm 0.1414$ \\
& $1500-1600 \mathrm{~h}$ & $0.0385 \pm 0.0061$ & $12.20 \pm 0.2828$ \\
Three years & $0900-1000 \mathrm{~h}$ & $0.0626 \pm 0.0060$ & $17.35 \pm 2.350$ \\
& $1500-1600 \mathrm{~h}$ & $0.0485 \pm 0.0064$ & $13.55 \pm 0.750$ \\
\hline
\end{tabular}

\section{OPTIMUM PLANTING DENSITY}

Planting density of rubber is determined considering the growth requirement of mature rubber trees. At the agronomic optimum, plants should capture and utilize growth resources in the most efficient manner providing the highest yield per unit area of land. Among the four main growth resources, i.e. $\mathrm{CO}_{2}$, light, nutrients and water, $\mathrm{CO}_{2}$ is highly dispersive in the atmosphere providing equal opportunity for each plant to access. Availability of nutrients for plant growth could be manipulated by adding the required quantity of fertilizer. If rubber is grown in wet areas, competition for soil water would be minimal but this could be a matter of concern in dry areas. Therefore, in general, light appears to be the most limiting factor and results in plants competing with one another. Competition between rubber trees begins at $c a$. $4^{\text {th }}$ year after planting when the sparse canopies of individual trees intermingle forming a closed canopy (Rodrigo et al., 1995; Obouayeba et al., 2005). Irrespective of the planting density, trees have more or less equal opportunity to capture light and other resources in the immature phase, particularly before the $4^{\text {th }}$ year of growth. Therefore, a higher planting density has an advantage of greater dry matter production per unit area during this early stage of growth. This has a carry-over effect in that the tree density with the highest growth or biomass production per unit area is above the density that captures maximum resources at a particular time point. For instance, LAI at maturity was found to be the same across a wide range of planting densities, i.e. between 500 and 800 trees per hectare. However, latex yield and total timber volume per hectare were high in high-planting densities despite the decrease in those values on a plant basis (Silva, 2007).
Similar status with respect to latex yields and light interception were also recorded earlier (Rodrigo et al., 1995).

Although clonal propagation is practiced to maintain homogeneity, heterogeneous rootstocks together with initial vigor in planting materials and spatial variability of edaphic and aerial environment create some level of heterogeneity in rubber plantations. This is advantageous for more vigorous plants under competitive conditions. Therefore, substandard plants have less opportunity to become tappable in high-density planting resulting in a greater percentage of runts being found under high compared to low densities. Although the absolute number of trees in tapping increases with the increase in planting density, the percentage of trees in tapping in higher densities is less than that in low densities (Silva, 2007). The highest density tested so far recorded was 1067 trees per hectare (Tiong et al., 1994) and most experiments recorded to date show a decline in yield per tree but an increase in yield per hectare with the increase in planting density (Tiong et al., 1994; Rodrigo et al., 1995; Saigian, 2000; Obouayeba et al., 2005). However, the rate of yield increase per hectare eventually declines so that the optimum density was found to be in the range of 500-700 trees per hectare.

Most of studies conducted so far on planting density of rubber have been confined to wet areas. However, one could expect to have a low level of optimum planting density in dry areas compared with that in wet areas due to the increased competition for soil water. Nevertheless, latex yield is influenced by the vapour pressure deficit in the environment and humid conditions limit latex coagulation resulting in prolonged latex flow and high 
yields. High plant density would create a high humid microclimate, hence the highest latex yield per hectare could be obtained by a density higher than that which leads to the highest amount of biomass. Also, higher densities would withstand strong winds more effectively resulting in a greater final number of trees. According to Roy et al. (2005) and Dey and Pal (2006), the percentage trees damaged by wind was lowest for the highest density of planting (824 trees per hectare) and highest for the lowest density (420 per hectare) in an experiment conducted at a windswept site at Tripura, India. As in most other studies, yield per tree decreased with the increase in planting density but yield per hectare increased in this study such that the highest yield was given by the highest density. However, maintaining a density of 600 trees per hectare appeared to be most suitable. An interesting feature of the above experiment was that rubber trees showed no positive response to additional doses of fertilizer at high densities. As discussed earlier, even here it can be seen that light is the most limiting factor for growth of the mature crop with a closed canopy and hence any additional application of fertilizer would be a waste.

Planting geometry is also an important factor in the determination of the optimum planting density. For convenience in crop management, rubber trees are grown in alleys/clusters and the distance between trees within the alley/cluster is less than that between alleys/clusters. Therefore, competition between trees could be separated into two categories, i.e. the competition within and between the alleys/clusters. If the space between trees is equal in all directions (e.g. square planting), then there would be no such distinction of competition as the magnitude of the above two types of competition would be the same. This would be ideal for tree growth; however there are some practical limitations when rubber is grown on sloped lands. Soil conservation practices would be rather expensive with a great number of terraces and, the walking distance for tapping and latex collection increases making harvesting more difficult. Also, canopy closure is quicker than in avenue planting systems and there is little space available for cultivating any other crop with rubber (Rodrigo et al., 2004). In the experiment of Rodrigo et al. (2004), light distribution at the ground level was demonstrated with different spatial arrangements of planting rubber at the density of 500 trees per hectare (Figure 1). When the gap between alleys/clusters is increased at a particular planting density, the distance within the alley/cluster decreases. With that, the competition among trees within alley/ cluster increases and the competition between alley/ cluster decreases. However, the former is compensated by the latter within a certain limit beyond which plant growth will be affected. Therefore, spatial arrangements complying with the grower's requirements are to be selected within these limits. Planting density of rubber adopted in different countries varies from 400 to 550 trees per hectare with different spatial arrangements. In Sri Lanka, a planting density of 500 trees per hectare is generally recommended with three types of spatial arrangements, i.e. $4.2 \mathrm{~m}$ x $4.8 \mathrm{~m}, 3.6 \mathrm{~m}$ x $5.4 \mathrm{~m}$ and $2.4 \mathrm{~m} \mathrm{x}$ $8.1 \mathrm{~m}$. The first one is advantageous on rocky lands where row arrangements are difficult. The second system is generally used on flat lands whilst the third one is met for short-term intercropping with other crops or to reduce terraces on sloped lands (Tillekeratne and Nugawela, 2001).

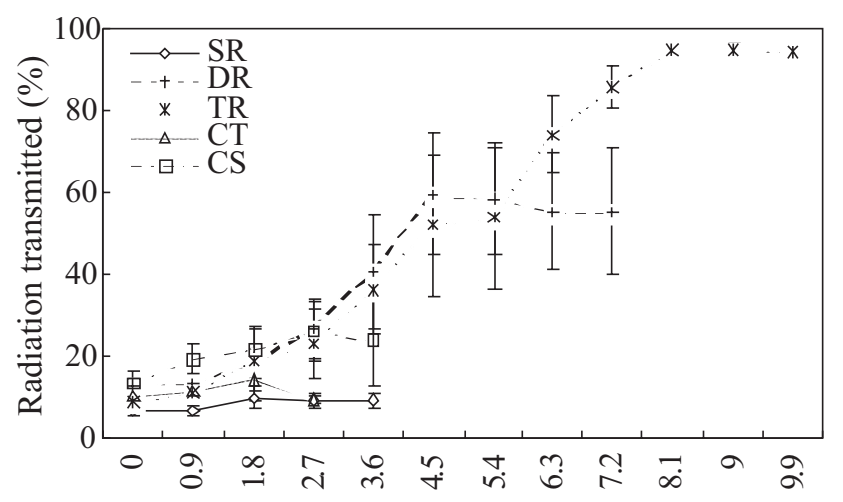

Distance from rubber row/cluster (m)

Figure 1. Radiation profile across the gap between rows/ clusters in different spatial planting arrangements of rubber. Values are for nine years after planting and represent a half of the transect. Planting density was constant at 500 trees ha ${ }^{-1}$ in all systems. Error bars represent SE of means where $n=6$ (i.e. for each half of the transect and three replicate plots). Treatment codes are: SR - single row, DR - double row, TR -triple row, CT three plant triangular cluster, and CS - four plant square cluster planting systems. Respective mean percentage of light penetration was 8.5, 35.3, 53.9, 11.5 and 21 (after Rodrigo et al., 2004). 


\section{RESOURCE CAPTURE IN INTERCROP- PING SYSTEMS}

During the initial stage of growth, rubber plants behave as discrete units with no canopy closure. This leads to temporal waste of resources, particularly light, resulting in excessive weed growth hence additional intercultivational activities with no direct financial benefits. Intercropping with short-duration crops provides an opportunity to utilize those resources enabling farmers to earn extra income during this no return period of rubber. A wide range of crops with different spatial arrangements and combinations has been tested on immature rubber lands. In such instances, land-use efficiency has increased with increase in overall growth and yield. This has clearly been associated with increased radiation use in intercrops, for instance, overall radiation use during the first two years of growth in rubber/banana intercropping was over threefold when compared with the values recorded for sole cropped rubber (Rodrigo et al., 2001). Except with grasses, crop combinations have shown no negative effects on the growth of rubber, on the contrary, in most cases intercropping has resulted in improved growth of rubber plants (Rodrigo et al., 1997; Rodrigo et al., 2001; Pathiratna and Perera, 2002). Among the indices for crop growth assessments in intercrops, Crop Performance Ratio (CPR) and Land Equivalent Ratio (LER) are suitable to evaluate the component crops separately and the cropping systems as a whole, respectively. The CPR assesses the productivity of the component crop with respect to its productivity in the sole crop and the proportional density in the intercrop (Azam-Ali et al., 1990); in contrast the LER is calculated from the sum of the ratio of the yield of the component crops in the intercrop relative to their sole crops showing the relative land area required as sole crops to produce the same yields achieved in the intercrop (Reddy and Willey, 1981; Willey, 1985). Values above unity for CPR and LER indicate the intercropping advantages of the particular component crop and the whole system, respectively. As an example, CPR value of intercropped rubber with banana was 1.48 whilst LER of the whole rubber/banana intercrop were recorded as 2.6 (Rodrigo et al., 1997).

Grasses appear to be competitive with rubber (Pathiratna and Perera, 2002) and this would be the case with natural weeds when rubber is left with no proper weeding. Unlike the sole crop of immature rubber, intercrops offer additional income attracting farmers' attention to the field. Improved growth of rubber in intercrops over the sole crop has also been attributed to this physical intervention resulting in proper care at the on-farm level. Nevertheless, a better understanding of physiological processes of the plants has shown other underlying factors for this improved growth.

It is well known that the light response of photosynthesis is curvilinear at the leaf level approaching light saturation above $1000 \mathrm{~mol} \mathrm{~m}^{-2} \mathrm{~s}^{-1}$ in rubber (Nugawela, 1989; Senevirathna et al., 2003). Nevertheless, in view of the fact that the majority of leaves in a crop canopy are shaded to different degrees, canopy photosynthesis operates at an almost constant photosynthetic efficiency for intercepted radiation. This results in a linear relationship between dry matter production and intercepted radiation with the slope of the relationship providing a measure of radiation-use efficiency (Monteith, 1994). During the early stage of growth, leaves of rubber plants are almost fully exposed to the incident light hence operating at or above the light saturation of photosynthesis, particularly during the mid hours of the day. Excessive radiation loads are stressful to the photosynthetic apparatus in that some level of photoinhibition related to the down-regulation of photosynthesis has been observed (Senevirathna et al., 2003). Moreover, around midday, a reduced rate of instantaneous photosynthesis associated with low water status of leaves and increased $r_{\mathrm{s}}$ have also been observed (Rodrigo, 1997). Partial shading in intercropping alleviates the radiation stress on rubber plants resulting in improved productivity. For instance, growth of rubber in rubber/banana intercropping showed higher growth than that in sole cropped rubber (Rodrigo et al., 1997) and this has been attributed to improved radiation-use efficiency (Rodrigo et al., 2001). This phenomenon is very common when rubber is grown under suboptimal conditions (e.g. in dry regions). Although dry conditions affect the growth of banana, rubber plants in the rubber/ banana intercrop in drier regions of Sri Lanka have shown higher growth than that in the sole crop even under smallholding conditions where no fertilizer was applied to banana (Rodrigo et al., 2003). Moreover, alleviation of radiation stress on photosynthesis around midday (Figure 2) and associated improved growth have been reported in rubber grown with sugarcane under smallholding conditions in a dry region of Sri Lanka (Rodrigo et al., 2000). 


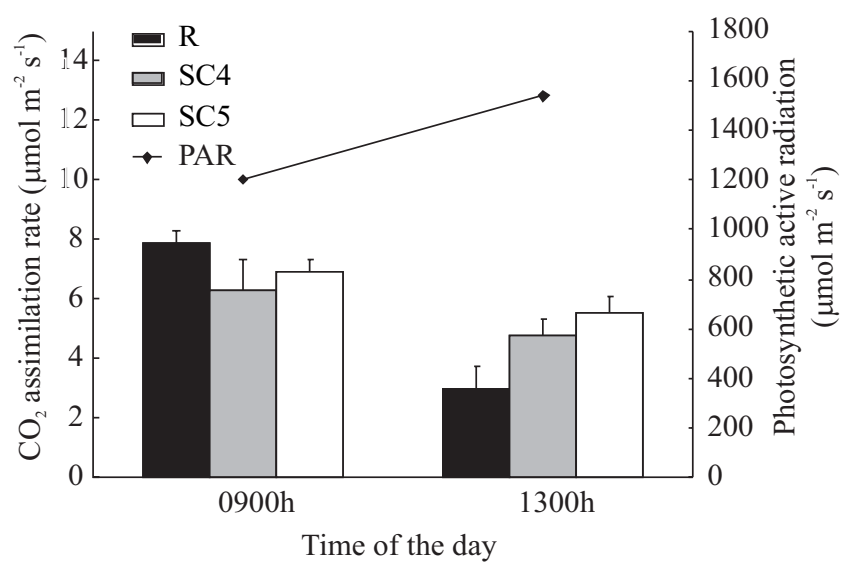

Figure 2. Diurnal variation in $\mathrm{CO}_{2}$ assimilation of rubber at leaf level in different cropping systems showing the capability of intercrops to alleviate the radiation stress on photosynthesis in the afternoon. Treatment codes $\mathrm{R}$, SC4 and SC5 refer to the sole rubber crop and intercropped rubber planted with four and five rows of sugarcane. Error bars represent SE of means where $n=4$. Incident light in terms of photosynthetic active radiation (PAR) for a given time interval is also shown (after Rodrigo et al., 2000).

In addition to the benefits associated with light use, heterogeneity of the root system in intercrops results in improved resource capture in the edaphic environment. For instance, total water consumption increased in rubber/banana intercropping (Rodrigo et al., 2005a) and increased dry matter per unit area in the same experiment (Rodrigo et al., 1997) provide evidence for greater nutrient uptake in intercrops over the sole crops. In intercropping systems, deep-rooted tree crops bring the nutrients from the lower soil horizons to the surface through leaf fall and make these available to the shallowrooted companion crops (Noordwijk et al., 1996). In addition, the close proximity of roots at different depths tends to reduce nutrient leaching.

With the understanding of the benefits in intercropping, attempts have been made to incorporate perennial crops with rubber. As observed with short-term and semi perennial crops, shade-tolerant perennial crops such as cocoa and coffee have been planted successfully with the standard density of rubber recommended for sole crops. Nevertheless, light penetration through the mature rubber canopy is not sufficient for sun-loving crops demanding new spatial arrangements for such intercropping systems (eg. rubber/tea, rubber/ cinnamon). Two approaches have been tried for improved light penetration: firstly, reduced planting density and secondly close planting of a few rows and then a wide gap for intercropping. The former reduces the intraspecific competition of rubber allowing a safe margin for the inter-specific competition. In the latter, intra-specific competition within the closely planted rows (clusters) increases whilst that between clusters decreases providing sufficient resources for other crops to grow. In Sri Lanka, rubber/tea intercropping is practiced with reduced planting density of rubber, i.e. ca. $75 \%$ of the sole crop density, with the spacing of $2.4 \mathrm{~m} \mathrm{x} 12 \mathrm{~m}$ (Rodrigo, 2001). Being a tree crop that is taller than most other crops, rubber dominates even in such systems and no sign of a negative effect of tea on rubber was observed (Iqbal et al., 2005). Instead, rubber showed an improved performance over the sole crop which could be a combined effect of low tree density and increased assess to nutrients given to tea. Placement of root barriers between rubber and tea crops in this system had no clear positive effect on tea growth unless the rubber canopy was pruned to improve the light penetration (Iqbal et al., 2005). Obviously, the shorter the crop the weaker it is in crop competition, as access to light is limited by the taller crop. Moreover, the reduced planting density (up to 75\%) has enabled the tea crop to produce a good harvest but for only up to about seven years, highlighting the needs for improved spatial arrangements. Planting rubber in paired rows without reducing the density has given improved light penetration. However, the gap between paired rows appeared not to be sufficient for long-term intercropping and also the spacing among rubber plants within the paired row did not allow rubber plants to grow adequately (Rodrigo et al., 2004). Therefore, a combination of the reduction in the planting density and the use of paired rows for improved light penetration are under investigation for long-term intercropping. The gaps used between paired rows were either 15 or $18 \mathrm{~m}$ whilst plants were placed within the paired rows at either $3 \mathrm{~m} \times 3 \mathrm{~m}$ or $3.5 \mathrm{~m}$ x $3.5 \mathrm{~m}$ spacing (Seneviratne, 2005). Growth performance of rubber trees planted in cluster planting systems (i.e. 3-4 plants within a closely planted cluster) was comparable with that obtained with traditional ways 
of planting at the standard planting density (Rodrigo et al., 2004). Nevertheless, there have been no proper records for such systems at reduced planting densities targeting long-term intercropping. Selective pruning of the rubber canopy would also be another option to improve light penetration and experiments are to be set up to investigate its influence on the overall productivity and the cost effectiveness.

In addition to the effect on photosynthesis in the understorey, improved light penetration through the rubber canopy in wide row intercropping systems appears to be beneficial in cooler climates. Rubber trees grown in the cooler climates of China are subject to freeze damage in the collar region of the tree and light penetration through the wide interrow gap between rubber rows in rubber/tea intercropping has led to temperature increase in the rubber tree trunk in winter with a minimum incidence of such damage (Feng et al., 1982). It is also expected that heterogeneous canopies in intercrops would conserve the heat inside the system through added resistance for heat transfer.

\section{CONCLUSIONS}

Principles in ecophysiology can effectively be used as a tool for productivity improvements in rubber cultivation. As for any crop, photosynthesis drives productivity of the rubber crop. Therefore, factors that govern and/or parameters that indicate the efficiency of photosynthesis under field conditions are the major determinants in the early selection process of Hevea genotypes for different environments. In order to overcome the drawbacks in the attempts made so far for early selection of genotypes in breeding programmes, simple models should to be developed that predict the canopy architecture of the mature crop through the characteristics of juvenile plants.

Rubber cultivation is in the process of expanding to nontraditional areas, particularly dry regions, to cater for the increasing demand for natural rubber. Being a plant that originated in the wet tropics, rubber performs suboptimally under dry conditions, particularly in the early stage of development. However, a farming system approach with the incorporation of other crops could be useful as a practical means to alleviate the radiation stress on rubber plants through the amelioration of the crop microclimate whilst improving the economic returns. With little information available on the effects of adaptive measures taken by rubber plants on overall canopy photosynthesis and latex productivity, water use studies of rubber in dry regions are to be conducted at the field level. Low temperatures (below $20^{\circ} \mathrm{C}$ ) affect the metabolic activities of the rubber tree resulting in low growth and yield. Assessments of photosynthetic efficiency in terms of quantum yield, light-saturated level of photosynthesis and chlorophyll $a$ fluorescence emission $\left(\mathrm{F}_{\mathrm{v}} / \mathrm{F}_{\mathrm{m}}\right)$ could be used as tools in genotype selection for such an environment.

The spatial and temporal efficiency by which plants acquire growth resources determines the overall productivity of rubber lands, hence the importance of optimum planting density and suitable crop combinations in intercropping systems. Light has been the most limiting factor in high-density planting and in intercropping systems. In general, increase in planting density of rubber results in decreased growth and yield per plant but increased yield per unit area. However, this rate of increase per unit area shows a declining trend with the increase in planting density. Hence optimum planting density of rubber has been recorded in the range of 500-700 trees per hectare. Nevertheless, high-density planting has proven to be effective in minimizing wind damage. At a particular density, spatial arrangement of planting rubber can be adjusted to a certain extent without compromising latex yields while being more convenient for crop management practices and for short-term intercropping. In order to facilitate long-term intercropping with sun-loving crop species, planting density may be compromised whilst moving to unorthodox spatial arrangements of planting rubber (e.g. paired row/cluster system of planting). With greater diversity, intercropping systems provide a more efficient way of resource capture and, in most cases, they ameliorate the crop microclimate facilitating improved growth and yield of rubber.

Acknowledgement: The author wishes to thank Dr. S.M.M. Iqbal and Ms. E.S. Munasinghe for their assistance in tracing the required literature. 


\section{REFERENCES}

Azam-Ali SN, Matthews RB, Williams JH, Peacock JM (1990) Light use, water use and performance of individual components of a sorghum/groundnut intercrop. Exp. Agric. 26:413-427.

Charles-Edwards DA (1982) Physiological determinants of crop growth. Academic Press, London.

Dey SK, Pal TK (2006) Effect of planting density on growth and yield of rubber (Hevea brasiliensis) in north eastern India. In: Preprints of the International Natural Rubber Conference. Ho Chi Minh City, Vietnam, pp.268-274.

Dey SK, Vijayakumar KR (2005) Photosynthesis and biomass production of three popular Hevea brasiliensis clones as affected by water stress. Nat. Rubber Res. 18:46-54.

Feng YZ, Wang HH, Zhang JH, Zhang KY, Ma WJ, Long YM (1982) Experimental and ecological studies on the rubber tea artificial community. Acta Bot. Sinica 24:164-171.

Hay RKM, Walker AJ (1989) An introduction to the physiology of crop yield. Longman Group, UK.

Iqbal SMM, Ireland CR, Rodrigo VHL (2005) Ecophysiological limitations to the productivity of tea in the rubber-tea intercropping systems. In: Preprints of the International Natural Rubber Conference. Cochin, India, pp.152-154.

Iqbal SMM, Rodrigo VHL (2006) Feasibility of rubber (Hevea brasiliensis Mull. Arg.) cultivation in the Eastern Province of Sri Lanka; a non traditional area for rubber. In: Preprints of the International Natural Rubber Conference. Ho Chi Minh City, Vietnam, pp.571-584.

Ireland CR, Long SP, Baker NR (1989) An integrated portable apparatus for the simultaneous field measurements of photosynthetic CO2 and water vapour exchange, light absorption and chlorophyll fluorescence emission of attached leaves. Plant Cell Environ. 12:947-958.

Monteith JL (1965) Evaporation and environment. Symposium of Society of Experimental Biology XIX:205-234.

Monteith JL (1994) Principles of resource capture by crop stands. In: Monteith JL, Scott RK, Unsworth MH (eds), Resource Capture by Crops, pp.1-15. Nottingham University Press, Leicestershire.
Monteith JL, Unsworth MH (1990) Principles of Environmetal Physics. ${ }^{\text {nd }}$ ed. Edward Arnold, London. Munasinghe ES (2005) Assessment on potential capability of fixing carbon in different genotypes of the rubber crop. Project Terminal Report on Climate Change Enabling Activity Phase II. Climate Change Secretariat. Environmental Economics and Global Affairs Division. Ministry of Environment and Natural Resources. Sri Lanka.

Noordwijk MN, Lawson G, Soumare A, Groot JJR, Hairiah K (1996) Root distribution of trees and crops: Competition and/or complementarity. In: Ong CK, Huxley P (eds), Tree-Crop Interaction: A Physiological Approach, pp.319-364. CAB International, Wallingford.

Nugawela A (1989) Gas exchange characteristic of Hevea genotypes and their use in selection for crop yield. Essex, University of Essex. PhD Thesis.

Nugawela A, Aluthhewage RK (1985) Gas exchange parameters for early selection of Hevea brasiliensis Muell. Arg. J. Rubber Res. Inst. Sri Lanka 64:13-20.

Nugawela A, Long SP, Aluthhewage RK (1995a) Genotypic variation in non-steady state photosynthetic carbon dioxide assimilation of Hevea brasiliensis. J. Nat. Rubber Res. 10:266-275.

Nugawela A, Long SP, Aluthhewage RK (1995b) Possible use of certain physiological characteristics of young Hevea plants in predicting yield at maturity. Indian J. Nat. Rubber Res. 8:100-108.

Obouayeba S, Dian K, Boko AMC, Gnagne YM, Ake S (2005) Effect of planting density on growth and yield productivity of Hevea brasiliensis Muell. Arg. Clone PB 235. J. Rubber Res. 8:257-270.

Pathiratna LSS, Perera MKP (2002) Contour and east-west row planting systems of rubber (Hevea) for intercropping. Part 1. Effect on growth and yield of component crops. J. Rubber Res. Inst. Sri Lanka 85:53-61.

Reddy MS, Willey RW (1981) Growth and resource use studies in an intercrop of pearl millet/groundnut. Field Crops Res. 4:13-24.

Rodrigo VHL (1997) Population density effects on light and water use of rubber/banana interculture systems of Sri Lanka. Wales, University of Wales, PhD Thesis.

Rodrigo VHL (2001) Rubber based intercropping systems. In: Tillekeratne LMK, Nugawela A (eds), Handbook of Rubber - Agronomy, pp.139-155. Rubber Research Institute of Sri Lanka, Sri Lanka. 
Rodrigo VHL, Nugawela A, Pathirathne LSS, Waidyanatha UPdeS, Samaranayake ACI, Kodikara PB, Weeralal JLK (1995) Effect of planting density on growth, yield, yield related factors and profitability of rubber (Hevea brasiliensis Muell. Arg.). J. Rubber Res. Inst. Sri Lanka 76:62-73.

Rodrigo VHL, Silva TUK, Munasinghe ES (2004) Improving the spatial arrangement of planting rubber (Hevea brasiliensis Muell. Arg.) for long-term intercropping. Field Crops Res. 89:327-335.

Rodrigo VHL, Stirling CM, Samarasekera RK, Kariawasam LS, Pathirana PAD (2000) Agronomic and economic benefits of high density banana intercropping during the immature period of rubber with particular emphasis on smallholders. J. Rubber Res. Inst. Sri Lanka 83:30-48.

Rodrigo VHL, Stirling CM, Silva TUK, Pathirana PD (2005b) The growth and yield of rubber at maturity is improved by intercropping with banana during the early stage of rubber cultivation. Field Crops Res. 91:23-33.

Rodrigo VHL, Stirling CM, Teklehaimanot Z, Nugawela A. (1997) The effect of planting density on growth and development of component crops in rubber/banana intercropping systems. Field Crops Res. 52:95-108.

Rodrigo VHL, Stirling CM, Teklehaimanot Z, Nugawela A. (2001) Intercropping with banana to improve fractional interception and radiation-use efficiency of immature rubber plantations. Field Crops Res. 69:237-249.

Rodrigo VHL, Stirling CM, Teklehaimanot Z, Samarasekera RK and Pathirana PAD (2005a) Interplanting banana at high densities with immature rubber crop for improved water use. Agron. Sustain. Dev. 25:45-54.

Rodrigo VHL, Stirling CM, Thennakoon S, Senivirathna AMWK, Pathirana PD (2003) Technology refinement of rubber/banana intercropping using a farmer participatory approach. Trop. Agric. Res. Ext. 6:77-84.
Roy S, Choudhury M, Eappen T, Chakraborty SK, Dey SK (2005) Effect of planting density and fertilizers on growth and early yield of rubber in Tripura. Nat. Rubber Res. 18:81-86.

Siagian N (2000) Effect of densities and planting system on rubber tree growth, latex yield and rubber wood volume on young Hevea rubber. Indon. J. Rubber 18:28-44.

Senevirathna AMWK, Stirling CM, Rodrigo VHL (2003) Growth, photosynthetic performance and shade adaptation of rubber (Hevea brasiliensis) grown in natural shade. Tree Physiol. 23:705-712.

Seneviratne P (2005) Plant Science. In: Tillekeratne LMK, Nugawela RCWMRA, Seneviratne WMG (eds), Annual Review, pp.24-49. Rubber Research Institute of Sri Lanka, Sri Lnka.

Silva TUK (2007) Effects of planting density on growth and yield of three different clones of Rubber (Hevea brasiliensis Muell. Arg.). MPhil thesis, University of Sri Jayawardenapura, Sri Lanka.

Teklehaimanot Z, Jarvis PG (1991) Direct measurement of evaporation of intercepted water from forest canopies. J. Appl. Ecol. 28:603-618.

Thornley JHM, Johnson IR (1990) A mathematical approach to plant and crop physiology. Oxford University Press, New York.

Tillekeratne LMK, Nugawela A (2001) Handbook of Rubber - Agronomy. Rubber Research Institute of Sri Lanka, Sri Lanka

Tiong GL, Seng CJ, Yee HC (1994) Economic evaluation of planting rubber as a dual purpose tree. International Planters Conference, Malaysia, pp.242-288.

Webster PR, Baulkwill BR (1989) Rubber. Tropical Agriculture Series, Longman Group, UK.

Willey RW(1985) Evaluation and presentation of intercropping advantages. Exp. Agric. 21:119-133. 